\title{
IMPROVING STUDENTS' OUTCOME USING GEOGEBRA INTERACTIVE MEDIA IN LEARNING DERIVATIVES
}

\author{
Happy Lumbantobing \\ University of Cenderawasih, Jayapura. Papua. Indonesia \\ E-mail: hlumbantobing@fkip.uncen.ac.id
}

\begin{abstract}
Abstrak
Tujuan penelitian ini adalah untuk mengkaji manfaat penerapan media interaktif GeoGebra dalam meningkatkan hasil belajar siswa dalam topik turunan fungsi. Penelitian adalah penelitian eksperimen dengan desain counterbalance. Populasinya adalah seluruh kelas XI SMA Negeri 3 Jayapura tahun pelajaran 2018/2019 yang terdiri dari empat kelas dengan jumlah siswa sebanyak 122 orang. Sampel diambil dengan menggunakan teknik purposive sampling untuk mendapatkan dua kelas eksperimen dengan jumlah siswa masing-masing 22 orang dan 26 orang. Kedua kelas eksperimen tersebut menerima perlakuan pembelajaran yang sama, yaitu pembelajaran menggunakan media interaktif GeoGebra dan pembelajaran tanpa menggunakan media interaktif GeoGebra yang dilakukan secara berurutan. Proses pembelajaran tersebut dilakukan empat kali secara bergantian pada kedua kelas eksperimen. Pengumpulan data dilakukan dengan melaksanakan pre tes dan pos tes pada setiap pembelajaran. Analisis data dilakukan dengan menggunakan uji statistik Wilcoxon Signed test dengan tingkat signifikansi (dua sisi) sebesar 0,05. Hasil penelitian menunjukkan bahwa terdapat perbedaan hasil belajar yang signifikan pada kedua jenis pembelajaran tersebut. Proses pembelajaran yang dirancang menggunakan media interaktif GeoGebra memperoleh hasil pembelajaran yang lebih unggul.
\end{abstract}

Kata kunci: Turunan fungsi, GeoGebra, Hasil belajar

\begin{abstract}
The purpose of this research is to consider the benefit of applying GeoGebra interactive media to improve student achievement in learning derivatives. This study was experimental research using counterbalance design. The population of the study was four classes of grade XI students of SMA Negeri 3 Jayapura academic year 2018/2019 consisting of 122 students. Purposive sampling was applied in this study to get two experimental classes with the number of students were 22 and 26 respectively. In both experimental groups received the same treatment which were learning using GeoGebra interactive media and learning without using GeoGebra interactive media which applied orderly. This process was implemented four times at both classes interchangeably. The data of the study was collected from participant's pretest and posttest at every learning treatment. Data was analyzed using Wilcoxon Signed test with the significance level (two-tailed) of 0.05. The result of the study shows that there are significant differences in learning outcomes of the two types of learning. The learning process which was designed using GeoGebra interactive media obtained the superior learning outcomes.
\end{abstract}

Keywords: Derivative, GeoGebra, Learning Outcome

\section{INTRODUCTION}

The use of computer-based learning technology as a medium of mathematics learning can visualize abstract concepts more clearly (Pilipovic \& Takaci, 2011; Navetta, 2016; Dockendorff \& Solar 2018). The use of interactive computer programs is an 
alternative solution to overcome students' difficulties in learning mathematics. Nowadays, there are many computer programs that can be used for learning mathematics, such as GeoGebra, Maple, SPSS, Matlab, and Geometer's Sketchpad. Hohenwarter developed the interactive GeoGebra program from 2001. The GeoGebra application and various forms of tutorials can be downloaded for free on the https://www.geogebra.org page. GeoGebra was construct to achieve students better understanding of mathematics. This software could be applied for active student learning and problem-oriented teaching; it develops mathematical learning experiments and discoveries not only in classroom but also at home (Hohenwarter \& Preiner 2007).

The GeoGebra software has various facilities that can be used to visualize or to demonstrate mathematical concepts. Learning using GeoGebra media can help students understand mathematical concepts, graphic properties of functions, and demonstrates mathematical concepts phenomena. Nobre et al. (2016) suggested that the use of GeoGebra media in the calculus learning process can help students to interpret concepts graphically. Furthermore, Bulut, Akcakin, and Kaya (2016) recommended using the GeoGebra application in teaching concept of fractions in elementary schools. Then, Zengin (2017) found that GeoGebra software is an effective tool to stimulate and to improve future mathematics teachers' understanding of mathematical proof. Sari, Hadiyan, and Antari (2018) explained that the dynamic nature of GeoGebra provides the possibility to look closely at the graph when the tangent is obtained from the secant line. This media could stimulate students' intuitive understanding of the definition of derivatives.

The use of GeoGebra software as an interactive media in the process of learning mathematics is useful in instilling a good understanding of mathematical concepts (Güyer, 2008; Hohenwarter \& Jones, 2007). Many studies, Bulut et al (2016); Lumbantobing (2018); Nobre et al. (2017); Sari, Hadiyan, \& Antari (2018); Tatar (2013); Zakaria \& Lee (2012); Zengin (2017); and Zengin, Furkan, \& Kutluca (2012), have examined the use of interactive mathematics software in mathematics learning. GeoGebra has a significant impact on mathematics learning process because the application can be used as a computer algebra system as well as an interactive geometry software. GoeGebra provides interactive animation applications in the fields of geometry, algebra, statistics and calculus applications. Based on the background above, it is essential to conduct research entitled “Improving Students' Outcome Using GeoGebra Interactive Media in Learning 
Derivatives".

\section{METHOD}

\section{Research Model}

This research is a quasi-experiment using counterbalanced design which is applied to two experimental classes.

\section{Sample}

Population of this research was four classes of grade XI students of SMA Negeri 3 Jayapura academic year 2018/2019 consisting of 122 students. This study adopted purposive sampling to get two experimental classes consisting of 22 and 26 students in each class.

\section{Research Design}

This study applied two different types of learning treatments to teach function derivatives. Treatment A was designed using GeoGebra interactive media and treatment B was a normal learning without using GeoGebra interactive media. Both types of treatment were applied to the two experimental classes in different orders.

Four sub-topics function derivatives were taught in these classes, so each experimental class got both treatment A and treatment B. The research was conducted over several days. Researchers applied counterbalanced design to control the order effects of treatments Shuttleworth (2018). Every time the treatment was done a pre-test and posttest took place. So, the progress of student learning could be seen immediately every time certain treatments were applied. The counterbalanced design used was adopted from the counterbalanced design model used by Lumbantobing (2018).

\section{Process}

Before conducting research, researcher trained the two experimental classes in the use of the GeoGebra application. The researcher conducted four lessons in accordance with the specified research design. Classes that were treated A were taught in the computer laboratory room, so that each student was free to explore the concept of function derivatives, the properties of functions based on their derivatives, the application of function derivatives and to draw graphics using the GeoGebra application. The students 
who were treated B were taught in the classroom without intervention. Researcher tested each group before and after the learning process by doing pre-test and post-test to see the students' learning progress.

\section{Outcome Test}

The learning outcomes test was constructed in line with the mathematics syllabus for derivatives subtopic determined by the Ministry of Education and Culture, Ministry of Education and Culture (2013). The test involved 20 items essay questions are taken from different test books. The outcomes test was designed to measure mathematical competency associated with the topics. The test was prepared by the researcher and validated by mathematics teachers who taught in both experimental classes.

\section{Data Analysis}

In this study, a total of 48 samples were analyzed using learning with treatment $\mathrm{A}$ and treatment $\mathrm{B}$. The pretest and posttest scores of the two experimental classes were analyzed. Normalized gain score data, Hake (1997), is obtained using the following formula,

$$
\mathrm{g}=(\mathrm{T} 2-\mathrm{T} 1) /(\mathrm{M}-\mathrm{T} 1),
$$

where $\mathrm{g}$ is normalized gain score, $\mathrm{M}$ is maximum score, $\mathrm{T} 2$ is posttest score, and $\mathrm{T} 1$ is pretest score.

The SPSS 24 for Windows application was implemented to analyze the data with the significance level (two-tailed) set at 0.05 . As the sample of this study was no more than 50, the Shapiro-Wilk test was used to determine whether the data obtained were normally distributed and the test of homogeneity of variances was used to determine whether the data obtained were homogeneous.

For the data was normally distributed and homogeneous, the paired samples t-test was performed and for the data that was not normally distributed or not homogeneous the paired samples Wilcoxon Signed Ranks test was implemented to test whether there was a significant difference between the data, Rajagopalan (2006).

\section{RESULTS}

The data normality based on the Shapiro-Wilk test and data homogeneity based on the test of homogeneity of variances are presented in Table 1. 
Table 1. Data Normality

\begin{tabular}{cccc}
\hline Learning process & Data & p-values & Distributions \\
\hline \multirow{2}{*}{ Treatment A } & Pretest & 0.000 & Not Normal \\
& Posttest & 0.093 & Normal \\
& Normalized Gain & 0.073 & Normal \\
& Pretest & 0.096 & Normal \\
Treatment B & Posttest & 0.161 & Normal \\
& Normalized Gain & 0.200 & Normal \\
\hline
\end{tabular}

Based on the distribution data of Table 1 and the homogeneity data of Table 2, nonparametric statistics was applied to analyze the data.

Table 2. Homogeneity Test

\begin{tabular}{cccccc}
\hline Data & Levene Statistic & df1 & df2 & Sig. & Homogeneities \\
\hline Pretest & 1.332 & 1 & 94 & 0.251 & Homogeny \\
Posttest & 10.991 & 1 & 94 & 0.001 & Not homogeny \\
N-Gain & 7.434 & 1 & 94 & 0.008 & Not homogeny \\
\hline
\end{tabular}

Based on Table 3, the results of Wilcoxon Signed Ranks 2-related samples comparing the pre-test of two types of learning show that there is no difference between the average pre-test of students taught using GeoGebra interactive media ( $\bar{x}=30.83$, SD $=13.16)$ and the students who were taught without using GeoGebra interactive media $(\bar{x}=31.49, \mathrm{SD}=16.20 ; \mathrm{Z}=-0.667, \mathrm{p}=0.505>0.05)$.

Table 3. Pretest Results Between Teaching Treatment

\begin{tabular}{cccccc}
\hline Pretest & N & Mean & SD & Z & Asymp Sig. (2-tailed) \\
\hline Treatment A & 22 & 30.83 & 16 & $-0.667^{\mathrm{b}}$ & 0.505 \\
Treatment B & 26 & 32.49 & 20 & & \\
\hline
\end{tabular}

$\mathrm{b}$ is based on negative rank.

Treatment A is learning with GeoGebra interactive media. Treatment B is learning without GeoGebra interactive media. Table 4 shows that there is a significant difference between the pre-test and post-test scores of students who are taught using GeoGebra interactive media design $(Z=-6.032, p<0.05)$. The difference is that students are more successful in answering exam questions after taking part in learning $(\bar{x}=70.15)$ than before taking part in the learning process $(\bar{x}=13.16)$. This finding can be interpreted as that learning designed using GeoGebra interactive media has an influence (meaningful effects) on the progress of student learning outcomes. 
Journal of Honai Math, Vol. 3, No. 1, pp. 101-110, April 2020

Lumbantobing, Improving Students' Outcome using Geogebra Interactive Media in Learning Derivatives

Table 4. Pre-test and Post-test Results of Treatment A

\begin{tabular}{cccccc}
\hline Tests & N & Mean & SD & Z & Asymp. Sig (2-tailed) \\
\hline Pre-test & 48 & 30.83 & 13.16 & & \\
Post-test & 48 & 70.15 & 11.00 & $-6.032^{\mathrm{b}}$ & 0.000
\end{tabular}

Treatment A is learning with GeoGebra interactive media.

$\mathrm{b}$ is based on negative ranks.

From Table 5, it is evident that there is a significant difference between the pretest and posttest scores of students who are taught without using GeoGebra interactive media $(Z=-6.032, p<0.05)$. The difference is that students are more successful in answering exam questions after taking part in learning $(\bar{x}=57.74)$ than before taking part in the learning process $(\bar{x}=32.49)$. This finding can be interpreted as that learning without using GeoGebra interactive media has an influence (meaningful effects) on the progress of student learning outcomes.

Table 5. Pretest and Posttest Results Treatment B

\begin{tabular}{cccccc}
\hline Tests & N & Mean & SD & Z & Asymp.Sig (2-tailed) \\
\hline Pretest & 48 & 32.49 & 16.20 & $-6.032^{b}$ & 0.000 \\
Posttest & 48 & 57.74 & 21.56 & & \\
\hline
\end{tabular}

Treatment B is learning without GeoGebra interactive media.

$\mathrm{b}$ is based on negative ranks.

Furthermore, to see the difference in the progress of student learning outcomes, normalized gain score data was calculated using the following formula:

$$
\mathrm{g}=(\mathrm{T} 2-\mathrm{T} 1) /(\mathrm{M}-\mathrm{T} 1),
$$

where $\mathrm{g}$ is normalized gain score, $\mathrm{M}$ is maximum score, $\mathrm{T} 2$ is posttest score, and $\mathrm{T} 1$ is pretest score. The normalized gain category of both learning models is given in the Table 6 , Hake (1998). Table 6 shows that normalized gain with medium and high categories is dominated by learning that is designed using GeoGebra interactive media.

Table 6. Category of Normalized Gain

\begin{tabular}{ccc}
\hline Category & Treatment A (\%) & Treatment B (\%) \\
\hline High & 14.58 & 10.42 \\
Medium & 77.08 & 56.25 \\
Low & 8.33 & 33.33 \\
\hline
\end{tabular}


Treatment A is learning with GeoGebra interactive media. Treatment B is learning without GeoGebra interactive media.

Table 7 shows that there is a significant difference between normalized gain scores of students taught using learning tools with GeoGebra interactive media $(Z=-3,940, p$ $<0.05)$. The difference are that students who are taught using learning tools with GeoGebra interactive media have a higher normalized gain $(\bar{x}=0.57)$ than students who are taught without using GeoGebra interactive media $(\bar{x}=0.40)$. This finding can be explained as that the use of GeoGebra interactive media has a meaningful effect on the progress of student learning outcomes on the topic of functional derivatives.

Table 7. Wilcoxon Signed Test Comparing Normalized Gain Between Treatments

\begin{tabular}{cccccc}
\hline N-gain & N & Mean & SD & Z & Asymp.Sig (2-tailed) \\
\hline N-gain of Treatment A & 48 & 0.57 & 0.14 & $-3.940^{\mathrm{b}}$ & 0.000 \\
N-gain of Treatment B & 48 & 0.40 & 0.24 & & \\
\hline
\end{tabular}

Treatment A is learning with GeoGebra interactive media. Treatment B is learning without GeoGebra interactive media $b$ is based on positive ranks

\section{DISCUSSION}

This study has argued the benefits of applying GeoGebra interactive media to improve student achievement in learning derivatives. The result of this study found that the progress of students taught using GeoGebra interactive media far exceeds the progress of students who are taught using regular learning without using GeoGebra interactive media. The results of this study are in line with the results of research conducted by Zengen, Furkan, and Kutluca (2012), and Lumbantobing (2018) who found that trigonometric learning using GeoGebra software is superior to learning without using GeoGebra.

Based on the normalized data acquisition, the progress of student learning outcomes taught using soft GeoGebra is in the medium category (77.08\%) and the high category $(14.58 \%)$. This shows that studying the topic of derivatives using the GeoGebra interactive media can help students to understand concepts, properties, graphical functions, characteristic of functions. Students obtained a great benefit by using GeoGebra software as they can learn independently using their own computer to explore, understand and see clearly through GeoGebra animation the graphs and behavior of functions and their derivatives, tangents, monotonous functions, extreme value functions. In this way, 
students' difficulties in learning the concept of derivatives can be overcome, as explained by Hohenwarter and Preiner (2007), Hohenwarter and Jones (2007), and Nobre, at. all (2016).

In addition, using GeoGebra interactive media will make it easier for teachers when teaching concepts and characteristics of derivative functions. The GeoGebra interactive media will allow teachers to visualize the function graphs of the characteristics found from their derivatives interactively, so students can understand them easily and quickly. This is consistent with the results of research conducted by Tatar (2013) which states the implementation of GeoGebra software in mathematics learning has a positive contribution.

This study has several limitations. Firstly, this research was not cost-effective as this requires computer devices for every student. Secondly, the teachers and students must have basic knowledge of computers. Finally, this study took only four compulsive derivative function subtopics; hence it did not cover the whole material of derivatives. Therefore, further research is needed.

\section{CONCLUSION}

Applying GeoGebra interactive media proves to be very beneficial in learning mathematics to improve student achievement in derived function studies. Based on data obtained from the pretest results, there is no significant difference between students who are taught with learning that is designed using GeoGebra interactive media and students who are taught by learning without using GeoGebra interactive media. Result analysis of pretest versus posttest of both types of learning showed that there was an improvement learning outcomes. However, the analysis of normalized gain data, found that there were significant differences in student learning progress of these types of learning, where learning progress using GeoGebra interactive media was higher than without using GeoGebra interactive media.

Considering the research finding, it is recommended that GeoGebra software should be widely socialized to mathematics teachers so they could implement not only to teach derivative topics but also other mathematics topics in order to improve student's achievement. Mathematics teacher could train the students to use GeoGebra software independently in learning mathematics. Further research is needed on the application of GeoGebra software in mathematics learning. 


\section{ACKNOWLEDGMENTS}

I would like to deliver my deepest thanks to the principal of SMA Negeri 3 Jayapura along with the mathematics teachers, and the students for allowing me to conduct this study. My special thanks to Dr. Maria Flutsch for editing my paper and giving several valuable suggestions. This research project was sponsored by the University of Cenderawasih, Jayapura-Indonesia with contract number: 283/UN20.2.2/PP/2019.

\section{REFERENCES}

Bulut, M., Akcakın, H. U., Kaya, G., \& Akçakın, V. (2016). The effects of GeoGebra on third grade primary students' academic achievement in fractions. International Society of Educational Research (ISER), Mathematics Education, 11(2), 347- 355.

Dockendorff, M., \& Solar, H. (2018). ICT integration in mathematics initial teacher training and its impact on visualization: the case of GeoGebra. International Journal of Mathematical Education in Science and Technology, 49(1), 67-84.

Güyer, T. (2008). Computer algebra systems as the mathematics teaching tool. World Applied Sciences Journal, 3(1), 132-139.

Hake, R. R. (1997). Evaluating conceptual gains in mechanics: A six thousand student survey of test data. AIP Conference Proceedings, 399, 595.

Hake, R. R. (1998). Interactive-engagement versus traditional methods: A six-thousandstudent survey of mechanics test data for introductory physics courses. American Journal of Physics, 66(1), 64-74.

Hohenwarter, M., \& Preiner, J. (2007). Dynamic mathematics with GeoGebra. Journal of online Mathematics and its applications, 7, 1448.

Hohenwarter M., \& Jones, K. (2007). Ways of linking geometry and algebra, the case of GeoGebra. Proceedings of the British Society for Research into Learning Mathematics, 27(3), 126-131.

Lumbantobing, H. (2018). The effect of interactive computer program on student accomplishment in teaching trigonometry. International Journal of Sciences: Basic and Applied Research (IJSBAR), 42(3), 38-48.

Ministry of Education and Culture. (2013). Peraturan menteri pendidikan dan kebudayaan Republik Indonesia nomor 69 tahun 2013 tentang kerangka dasar dan struktur kurikulum Sekolah Menengah Atas/Madrasah Aliyah. Retrieved on June 11, 2019 from http://biologi.fkip.uns.ac.id/wp- content/uploads/2013/08/PDK- 


\section{3-69-Kerangka-Dasar-Kurikulum-Kompetensi- SMA.pdf}

Navetta, A. (2016). Visualizing functions of complex numbers using Geogebra. North American GeoGebra Journal, 5(2), 17-25.

Nobre, C. N., Meireles, M. R. G., Junior, N. V., de Resende, M. N., da Costa, L. E., \& da Rocha, R. C. (2016). The use of GeoGebra software as a calculus teaching and learning tool. Informatics in Education. Journal of Eastern and Central Europe, $15(2), 253-267$.

Pilipovic, S., \& Takaci, D. (2011). On the delta distribution: Historical remarks, Visualization of delta sequences. Teaching Mathematics and Mathematics in Science. Retrieved on March 6, 2019 from https://pdfs.semanticscholar.org/b9e8/ 5e317180631c4509c491e9c785ec41743e0b.pdf

Rajagopalan, V. (2006). Selected statistical tests. New Delhi: New Age International (P) Ltd.

Sari, P., Hadiyan, A., \& Antari, D. (2018). Exploring derivatives by means of GeoGebra. International Journal on Emerging Mathematics Education, 2(1), 65-78.

Shuttleworth, M. (2018). Counterbalanced measures design. Retrieved on March 6, 2019 from https://explorable.com/counterbalanced-measures-design

Tatar, E. (2013). The effect of dynamic software on prospective mathematics teachers' perceptions regarding information and communication technology. Australian Journal of Teacher Education, 38(12), 1-16.

Zakaria, E., \& Lee, L. S. (2012). Teachers' perceptions toward the use of GeoGebra in the teaching and learning of mathematics. Journal of Mathematics and Statistics, 8(2), 253-257.

Zengin, Y. (2017). The effects of GeoGebra software on pre-service mathematics teachers' attitudes and views toward proof and proving. International Journal of Mathematical Education in Science and Technology, 48(7), 1002-1022.

Zengin, Y., Furkan, H., \& Kutluca, T. (2012). The effect of dynamic mathematics software GeoGebra on student achievement in teaching of trigonometry. ProcediaSocial and Behavioral Sciences, 31, 183-187. 